\title{
Saroj Nalini Arambam Parratt
}

\section{$(1933-2008)$}

Arambam Saroj Nalini was born in Imphal, in the then princely state of Manipur, on June $2^{\text {nd }}$ I933. Her father was a well-known and respected educationalist and government officer. During the war years he was posted to Jiribam, where she received her first education, and later transferred to a convent school in Haflong. She proceeded to Calcutta University, where she became the first Meetei woman to obtain BA and MA degrees, majoring in Philosophy. While in Calcutta she enjoyed close friendship with Christian Naga students, and converted to Christianity. She was baptised at the Lower Circular Road Baptist church, whose minister, Walter Corlett had himself served in Imphal during the war years. The Christian faith was to become a dominant influence on her future life. She came to Britain in the late I950s to study theology, and obtained a Bachelor of Divinity degree from London University in I96I. Shortly after she married John Parratt. When their desire to work in India was frustrated they decided to work elsewhere in the developing world, initially in Nigeria, where Saroj became a tutor in philosophy at the University of Ile-Ife. When her husband was offered a research fellowship by the Australian National University she enrolled for a PhD in the Department of Asian Studies there, under the supervision of the eminent indologist A.L.Basham. Despite the frequent absences of her husband on field work in Papua-New Guinea and having to care for three young children, the bulk of the thesis was completed before she returned to Manipur for further extended field work in I972. The doctorate was awarded three years later, one of her examiners being Professor Suniti Kumar Chatterji, who (unusually for the time) himself had a deep interest in India's north-eastern region. Her thesis was published in I980 (Firma KLM, Calcutta) as The Religion of Manipur. It marked the beginning of a new phase in writing on Manipur by its rigorous application of critical methodology both in the collection and in the analysis of field data, and had considerable influence on younger Meetei scholars.

From I975-90 she taught at institutions in southern Africa, including the universities of Malawi and Botswana. She published a number of important papers including a seminal study of Islam in Botswana and studies of Christianity among Tswana women. Her main research however remained the Meetei, and she spent lengthy periods on field work in Manipur. She developed a close relationship with the University of Manipur, and was appointed an honorary professor there in 200I. The fruit of this research, besides numerous academic papers, was two books jointly authored with her husband. Queen Empress vs. Tikendrajit, the Anglo-Manipuri Conflict of 1891 (Vikas, New Delhi, I992) was a critical account, based on detailed archival and oral sources, of the most traumatic event in Manipur's history. By contrast The Pleasing of the Gods: Meitei Lai Haraoba (Vikas, New Delhi, I997) was the result 
of meticulous field work, being an analysis and interpretation of the oral text, music and dance of the pre-Hindu religious festival which lies at the heart of Meitei culture.

Before she left Botswana in 2000 Saroj had already been concerned to produce an accurate translation of the Cheitharol Kumpapa, the Court Chronicle of the Kings of Manipur. On a visit to Imphal she had the unique privilege of being invited by the head maichou (court scribe) to photocopy the whole manuscript of the authenticated chronicle which was in his keeping. She quickly mastered the archaic script (meetei mayek) and the scribal conventions. She became an honorary fellow of the Institute for Textual Scholarship and Electronic Editing of the University of Birmingham and began the translation which would occupy the remainder of her life. The publication was sponsored by the Royal Asiatic Society, and would include a fairly literal translation into English and explanatory notes as well as a facsimile of the original text. Volume I appeared in 2005 The Court Chronicle of the Kings of Manipur: the Cheitharol Kumpapa (Routledge, London and New Delhi), and the second volume is expected in 2009. During the time she was working on the second volume she was already suffering from terminal illness, and just a week before her death she finished the draft translation of the final volume (up to I 89I), thus completing a work which is likely to remain a standard text for scholars working on the Indo-Burma region.

Saroj Nalini Arambam Parratt earned widespread respect in north-east India, both for her scholarship and for her advocacy of the distinct identity of the Mongoloid peoples of the region as contrasted with the sanskritic tradition of the sub-continent. Her contribution to our understanding of the history and culture of the Meetei is probably unparalleled.

John Parratt 